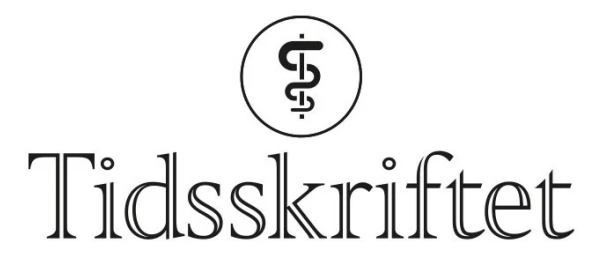

DEN NORSKE LEGEFORENING

\title{
Utviklingshemmede og bruk av tvang ved vaksinering mot covid-19
}

KOMMENTAR

TORSTEIN VIK

torstein.vik@ntnu.no

Torstein Vik er professor emeritus i barnesykdommer, Norges teknisk-naturvitenskapelige universitet.

Forfatteren har ikke oppgitt noen interessekonflikter.

Denne innsiktsfulle kronikken er i disse tider spesielt relevant for foreldre til utviklingshemmede og autister. Nylig ble Frode Larsen, en 45 år gammel mann med autisme, nektet vaksine av Statsforvalteren i Vestfold og Telemark (1). Bruken av tvang, som var at far skulle holde rundt Frode for å berolige han, sto ikke i forhold til nytten. Fastlegen, personalet i boligen og foreldrene mente at vaksinering ville være til Frodes beste. Om han ikke fikk vaksine kunne annen tvang som isolering bli nødvendig. Det er mulig at Statsforvalteren mente Frode ikke hadde spesiell risiko for å bli syk eller for å få et alvorlig forløp, og at han senere ville være beskyttet av flokkimmunitet.

Nyere studier fra USA viser imidlertid at utviklingshemmede både har større risiko for å bli smittet med covid-19 (므), og for å dø om de blir syke, enn den generelle befolkningen $(\underline{2}, 3)$. Det er flere mulige grunner til den økte risikoen. Blant annet har mennesker med Downs syndrom redusert cellulær og humoral immunitet (4). Dette medfører høy forekomst av luftveisinfeksjoner, og bidrar til økt dødelighet av pneumoni og influensa. Det er altså svært gode grunner til at utviklingshemmede og autister bør vaksineres mot covid-19, og at vaksineringen av disse også bør prioriteres. Det er derfor vanskelig å forstå at det er uforholdsmessig bruk av tvang å la en far holde omsorgsfullt rundt sin sønn mens sønnen får vaksine.

Jeg lurer på hvordan dette regelverket skal forstås i forhold til barnevaksinasjonsprogrammet? De fleste sped- og småbarn holdes omsorgsfullt av sine foreldre ved vaksinering. Likevel er det noen barn som blir engstelige og begynner å protestere, og de holdes derfor litt fastere. Mener Statsforvalteren at dette er uforholdsmessig bruk av tvang? Bør slike tilfeller legges frem for Statsforvalteren før vaksinering eventuelt kan gjennomføres?

Jeg er takknemlig for synspunkter fra Jorem og medarbeidere. 


\section{LITTERATUR}

1. Persen K, Fjelltveit I, Graf C. https://www.tv2.no/a/13920798/. Lest 14.4.2021.

2. Gleason J, Ross W, Fossi A et al. The Devastating Impact of Covid-19 on Individuals with Intellectual Disabilities in the United States. https://catalyst.nejm.org/doi/full/10.1056/CAT.21.0051. Lest 14.4.2021.

3. Turk MA, Landes SD, Formica MK et al. Intellectual and developmental disability and COVID-19 case-fatality trends: TriNetX analysis. Disabil Health J 2020; 13: 100942. [PubMed][CrossRef]

4. Malt EA, Dahl RC, Haugsand TM et al. Helse og sykdom hos voksne med Downs syndrom. Tidsskr Nor Legeforen 2013; 133: 290-4. [PubMed][CrossRef]

Publisert: 7. juni 2021. Tidsskr Nor Legeforen. DOI:10.4045/tidsskr.21.0399

(C) Tidsskrift for Den norske legeforening 2023. Lastet ned fra tidsskriftet.no 26. april 2023. 